\title{
Exploratory development of PCR-fluorescent probes in rapid detection of mutations associated with extensively drug- resistant tuberculosis
}

JIANQIN Liang

Chinese PLA General Hospital

JIN Zhou ( $\square$ huoshan1975@sina.com )

the Eighth Medical Center of Chinese PLA General Hospital https://orcid.org/0000-0002-8541-3693

YUQIN Liu

Institute of infectious diseases of Heilongjiang

YUAN Gao

CapitalBio Corp

GUANGXIN Xiang

CapitalBio Corp

ZHI Chen

Chinese PLA General Hospital

WANLI Xing

Tsinghua University School of Medicine

\section{Research}

Keywords: PCR-fluorescent probe, extensively drug resistance, mycobacterium tuberculosis, drug susceptibility testing

Posted Date: September 30th, 2020

DOI: https://doi.org/10.21203/rs.3.rs-67817/v1

License: (c) (i) This work is licensed under a Creative Commons Attribution 4.0 International License. Read Full License

Version of Record: A version of this preprint was published at European Journal of Clinical Microbiology \& Infectious Diseases on April 1st, 2021. See the published version at https://doi.org/10.1007/s10096-021-04236-z. 


\section{Abstract \\ Background}

The diagnosis and treatment of drug resistant tuberculosis (TB) especially multidrug-resistant (MDR) and extensively drug-resistant (XDR) tuberculosis are the critical and difficult factors in the prevention and control of tuberculosis. The development of rapid molecular diagnostic tools become more and more significant to improve the cure rate, decrease the risk of recurrence and death rate. Currently, molecular mechanisms of drug resistance and major drug-resistant genes of Mycobacterium tuberculosis (MTB) have been analyzed and elucidated. We put into use PCR-fluorescent probes to detect the mutation gene associated with XDR-TB and evaluate the clinical value of PCR-fluorescent probes.

\section{Methods}

The molecular species identification of 900 sputum specimens was performed with the use of PCR-fluorescent probe method, wherein the mutations of the drug resistance genes including rpoB, katG, inhA, embB, rpsL, rrs and gyrA were detected, and the conventional drug susceptibility testing(DST)and PCR-directed sequencing(PCR-DS) was carried out as control.

\section{Results}

Among the 900 positive sputum specimens, the result of DST demonstrated that there were 501 strains of rifampicin-resistance, 451 strains of isoniazid-resistance, 293 strains of quinolone-resistance, 425 strains of streptomycin-resistance, 235 strains of ethambutol-resistance, and 204 strains of Amikacin-resistance. 427(47.44\%) strains were MDR-TB. 146 (16.22\%) strains were XDRTB. The mutations of the rpoB, katG, inhA, embB, rpsL, rrs, and gyrA genes were detected in 751 of 900 specimens of MTB by PCRfluorescent probe method, and the detection rate of drug resistance was 751/900 (83.44\%). No mutant genes were detected in the other 149 specimens. Compared with DST, the mutant detection rate of rpoB, katG/inhA, rpsL, rrs, embB, and gyrA of six drugs (RIF,INH,SM,AM,EMB,FQs) were larger than $88 \%$, five of six drugs were larger than $90 \%$ except for SM $₫ 88.11 \% \bigotimes$. The MDR mutant gene types were found in 398 specimens (42.22\%), and XDR mutant gene types were found in 137 specimens (15.22\%). PCR-DS was also employed and confirmed the PCR-fluorescent probe method with the accordance rate of $100 \%$.

\section{Conclusion}

The PCR-fluorescent probe method is simple and rapid in detection of genotypes of XDR-TB and is worthy to be applied in the hospital.

\section{Background}

Tuberculosis is a chronic infectious disease caused by mycobacterium tuberculosis. According to Global tuberculosis report 2019 [1], in 2018, there were 10 million new tuberculosis (TB) cases, 380,000 Multidrug-resistant tuberculosis (MDR-TB) cases and 1.45 million deaths. $3.4 \%$ of new patients and $18 \%$ of retreat-patients were MDR-TB and rifampicin resistant tuberculosis (RR-TB), among which extensively drug-resistant tuberculosis (XDR-TB) accounted for $6.2 \%$, and 1.45 million cases died, and nearly 210,000 patients died due to MDR/RR-TB. There were 866,000 new TB cases in China, 66,000 cases of rifampicin resistance and 38,800 deaths, ranking the second in the world for many years. But only one-third of the patients had access to treatment, far from achieving the goal of end TB. MDR-TB is defined as infected Mycobacterium tuberculosis that is resistant to at least both isoniazid (INH) and rifampicin (RFP) in vitro. XDR-TB refers to the infected Mycobacterium tuberculosis that is not only resistant to INH and RFP, also at the same time resistant to at least one kind of fluoroquinolones and a second-line anti-TB drugs injection (kanamycin, amikacin, capreomycin). Once healthy people inhaled resistant mycobacterium tuberculosis, which was exhaled into air by tuberculosis patients through cough, sneeze or spit, it will develop as resistant tuberculosis in certain period of their lives.

As the slowly growth of mycobacterium tuberculosis, the diagnosis and drug resistance detection become a challenging problem in clinical treatment. The delayed diagnosis resulted in improper treatment of tuberculosis patients and increasing rate of drug

Page $2 / 11$ 
resistance of mycobacterium tuberculosis which seriously influenced the effect of the treatment. The emergence and transmission of MDR-TB and XDR-TB, which hindered the control of tuberculosis infection, thereby developed as a stubborn disease. The MDR/XDR-TB are the critical reasons for the high lethality of tuberculosis.

Generally, there are three types of drug resistance mechanisms in mycobacterium tuberculosis(MTB): (1) reducing cell's membrane permeability and efflux pump mechanism; (2) generating catabolic and inactivated enzymes; (3) alteringdrug target locus. Chromosome mediated drug resistance is the main basis of MTB drug resistance [2]. At present, the research of MTB drug resistance mechanism is mainly focused on the drugs targeted locus and the mutations related genes. The current first-line drugs for the treatment of tuberculosis including isoniazid, streptomycin, rifampicin, pyrazinamide and ethambutol, and the second-line drugs consisting of fluoroquinolones (Levofloxacin, Moxifloxacin), ethionamide and protionamide, and injectable drugs such as aminoglycoside (kanamycin and amikacin) and polypeptide antibiotic (capreomycin). Currently, major drug-resistant genes of Mycobacterium tuberculosis have been analyzed and identified. The drug resistant mechanism of isoniazid, an anti-tuberculosis chemotherapy drug, is rather complicated, with $92 \%$ of the INH resistant isolates associated with gene mutations from katG, inhA and ahpC [3-6];Rifampicin (RFP) is targeting on a DNA dependent RNA polymerase subunit $\beta$ (rpoB) in mycobacterium tuberculosis, with $95 \%$ of the RFP resistant isolates associated with gene mutations from rpoB gene mutations. The detection of rifampin resistance is a paramount indication of the MDR-TB[7, 8]; embB gene mutation interpreted the major molecular mechanism of the $50 \%-60 \%$ of EMB resistance[9, 10]; Of $80 \%$ clinical SM resistant isolates of mycobacterium tuberculosis were detected mutations in rpsL or rrs gene[11, 12]; Fluoroquinolones(FQs) included moxifloxacinఐMfx区, levofloxacin(Lfx) and others. Mutations of gyrA gene are related to drug concentration and structure causing medium and high drug resistanceof FQs, while gyrB gene mutation might result in lowly drug resistance of FQs by altering drug accumulation in the cell $[13,14]$. Mutations associated with resistance to amikacin (AM) are located within rrs, which encodes the ribosomal $16 \mathrm{~S}$ rRNA. The $60.5 \%$ of mutation was single base substitution of $1401 \square A \rightarrow G \rrbracket$. A minority of isolates were $1402(C \rightarrow T$ or $A), 1484(G \rightarrow T)$ which occurred mainly on the highly resistance strains [15]. The mutation of pncA accompanied with decrease or loss of PZase activity is the main reason of pyrazinamide (PZA) resistance [16].

Currently, the routine clinical bacteriological laboratory examinations on tuberculosis are microscopic smear and culture method. Conventional mycobacterium culture and drug sensitivity detection method, BactecMGIT960, has been used as the gold standard for drug resistance diagnosis in tuberculosis laboratories, but its detection cycle is too long to provide timely detection results for clinical practice [17] .GeneXpert MTB/RIF assay (Cepheid, Sunnyvale, CA) is a new technology that can detect both Mycobacterium tuberculosis and rifampicin resistance, but its biggest drawback is that it can only detect rifampicin resistance, not other first-line and second-line drugs[18-21]. In this study, we developed a mutation detection system of resistance with isoniazid (INH), rifampicin (RFP), streptomycin (SM), ethambutol (EMB), amikacin (AM) and fluoroquinolones (FQs) included moxifloxacin and/or levofloxacin by rapid detecting clinical sputum specimens with PCR fluorescence probe method, providing guidance to both establish the suitable MDR/XDR mutations detection system and carry out effective and individualized treatment in the early stage.

\section{Materials And Methods}

\subsection{Collection of sputum specimens}

We collected 900 cases of morning sputum specimens from tuberculosis patients in the tuberculosis department of the Eighth Medical Center of the PLA General Hospital and Heilongjiang Chest Hospital from January to December in 2018. All the 900 sputum samples were positive for acid-fast staining with Ziehl-Neelsen method [22].

\subsection{Instruments and reagents}

Mycobacterium nucleic acid detection reagent, fluorescence detection reagent of MTB nucleic acid amplification and Real time Fluorescence Quantitative PCR instrument (ABI7700) were provided by CapitalBio Corporation, Tsinghua University, Beijing.

\subsection{Methods}

\subsubsection{Phenotypes drug susceptibility testing(DST)}


The rapid culture and drug sensitivity tests of the BACTEC MGIT 960 System (BD Diagnostic, USA) were conducted in accordance with the operation sequence in the "TB Laboratory Standardization Operation and Network Establishment"[22].

\subsubsection{PCR fluorescence probe method [23]}

The Ct value of the positive control should be lower than 40 , and Ct value of the negative control should more than 40 . If the result of any of the control is false, the results of all the samples in one experiment is defined invalid and need to be redetected.

\subsubsection{PCR-directed sequencing(PCR-DS)}

A total of $20 \mu$ PCR products will be sent to the Invitrogen (Shanghai) Trading Co. Ltd for the further verification of sequencing.

\subsection{Evaluation method}

With the BACTEC MGIT 960 System (BD, USA) drug sensitivity results as the standard, the sensitivity and specificity of PCRfluorescence probe method and the detection coincidence rate of the two methods were evaluated. PCR-DS was used to verify the accuracy of PCR- fluorescence probe method and compare the consistency rate of drug resistance detection between PCRfluorescence probe method and PCR-DS.

\section{Results}

\subsection{Molecular species identification [23]}

900 specimens of acid fast staining positive sputum were identified by PCR fluorescence probe method. The results indicated that all the 900 specimens belong to mycobacterium tuberculosis complexes.

\subsection{Drug susceptibility testing(DST)}

\subsubsection{Phenotypic drug susceptibility testing (DST)}

The 900 clinical culture isolates were analyzed by conventional drug susceptibility testing(Table 1), 501 were RFP-resistant strains (55.67\%), 399 were RFP-susceptible strains (44.33); 451 were INH-resistant strains (50.11\%), 449 were INH-susceptible strains (49.89\%); 293 were FQs-resistant strains (32.56\%), 607 were FQs-susceptible strains (67.44\%); 235 were EMB-resistant strains (26.11\%), 665 were EMB-susceptible strains (73.89\%); 425 were SM-resistant strains (47.22\%), 475 were SM-susceptible strains (52.78\%); 204 were AM-resistant strains (22.67\%), 696 were AM-susceptible strains (77.33\%).

427 (47.44\%) of strains were resistant to both RFP and INH and were MDR-TB cases. 146 (16.22\%) strains were resistant to all six drugs and were XDR-TB cases.

\subsubsection{PCR fluorescence probe method}

We analyzed 900 clinical sputum specimens by PCR fluorescence probe method, 480 specimens were rpoB gene mutant type as RFP -resistance,(53.33\%), 420 specimens were rpoB gene wild type as RFP-susceptible(46.67\%); 241 specimens were KatG gene mutant type(26.78\%), 145 specimens were inhA gene mutant type(16.11\%) as INH-resistance, 514 specimens were KatG/inhA wild type as INH-susceptible(57.11\%); 239 specimens were gyrA gene mutant type as FQs-resistance(26.56\%), 661 specimens were gyrA gene wild type as FQs-susceptible(73.44\%); 190 specimens were embB gene mutant type as EMB-resistance(21.11\%), 710 specimens were gyrA gene wild type as EMB-susceptible(78.89\%); 342 specimens were rpsL gene mutant type as SMresistance(38.00\%), 558 specimens were rpsL gene wild type as SM-susceptible(62.00\%); 163 specimens were rrs gene mutant type as AM-resistance(18.11\%), 737 specimens were rrs gene wild type as AM-susceptible(81.89\%)(Table 1).

The mutations of the rpoB, katG, inhA, rpsL, rrs, embB and gyrA genes were detected in 751 of 900 specimens by PCR-fluorescent probe method, and no mutant genes were detected in the other 149 specimens as wild types. The rpoB, katG/inhA mutant types were found in 398 specimens (44.22\%) which were MDR gene mutant types, and the related cases were MDR-TB. The rpoB, katG/inhA, gyrA, rpsL and rrs mutant types were simultaneously found in 137 specimens (15.22\%), and the related cases were XDRTB.

\subsubsection{DNA sequencing (DS)}


Among the 900 clinical sputum specimens, 480 specimens (53.33\%) were found eight mutations in five loci (T511C, A516T, C526T, A526G, C526G, A526T, C531T, and T533C) associated with rpoB gene, 420 specimens were found no mutation within rpoB gene; 241 specimens (26.78\%) were detected two mutations (G315C,G315A) associated with the katG gene, 145 specimens (16.11\%) harbored one mutation (C-15T) in the inhA gene and 514 specimens were detected no mutation in both katG and inhA gene; 239 specimens (26.56\%) were found two mutations (C90T, A94G) associated with the gyrA gene, 661 specimens were found no mutation in the gyrA gene; 190 specimens (21.11\%) were detected two mutations (A306G, G306A) associated with the embB gene, 710 specimens were detected no mutation in the $e m b B$ gene; 342 specimens $(38.00 \%)$ harbored two mutations (A43G, A88G) in the $r p s L$ gene, 558 specimens were found no mutation in the $r p s L$ gene. 163 specimens $(18.11 \%)$ were found three mutations (A1401G, C1402T, G1484T) in the rrs gene, 737 specimens were found no mutation in the rrs gene (Table 1).

\subsection{Statistical analysis}

According to Table 2, we can conclude that the lowest positive coincidence rate of PCR-fluorescent probe method comparing with DST for the detection of amikacin was $75 \%$, and the other drugs were higher than $75 \%$, which showed that these two methods have good consistency in positive coincidence rate. At negative coincidence rate, all six drugs were larger than $97 \%$ which indicated that those methods have good consistency. In total coincidence rate, all six drugs were larger than $88 \%$, five of which drugs were larger than $90 \%$. Above all, the results revealed that both PCR-fluorescent probe method and DST have good consistency in the total coincidence rate of drugs resistance.

As Table 3 showed that both the positive coincidence rate and the negative coincidence rate of the PCR-fluorescent probe method comparing with PCR-DS were $100 \%$, besides, the total coincidence rate was $100 \%$. Additionally, the statistical results illustrated the detection results of all the seven drug resistant genes by PCR-fluorescent probe method have good consistence with PCR-DS.

\section{Discussion}

The diagnosis and treatment of drug resistant tuberculosis especially MDR/XDR-TB are the critical and difficult factors in the prevention and control of tuberculosis. Currently, the conventional culture-based techniques have long turnaround times, we cannot offer timely and effective treatment programs for tuberculosis patients especially those combined with HIV patients [24]. In 2010, WHO endorsed the GeneXpert MTB/RIF assay (Cepheid, Sunnyvale, CA) [25] that used real-time PCR to identify M. tuberculosis complex DNA and the mutations associated with RFP resistance directly from sputum specimens. But Xpert MTB/RIF assay cannot detect mutations associated with other anti-tuberculosis drug such as INH, EMB, SM, AM, FQs. With the deeply research on the molecular mechanism of drug resistance, the establishment of a simple, fast and accurate method for the detection of drug resistant mutations become more and more significant to improve the cure rate, reduce the occurrence of drug resistance, decrease the risk of recurrence and death rate.

PCR fluorescence probe technology is to use double PCR technology and the Taqman probe technique to detect mycobacterium tuberculosis and drug resistance by monitoring the fluorescence signal of different fluorescent channels. This technique has strong specificity, sensitivity, and easy to operate, etc. Our previous study [23] showed that PCR fluorescence probe technology is important clinical value in the rapid diagnosis of tuberculosis in sputum specimens. However, there are few studies on exploratory development of PCR-fluorescent probes in rapid detection of mutations associated with XDR-TB.

This study is based on the PCR-fluorescent probe method which has a low cost, simple operation and only need 1.5 hours to the detect the nucleic acid from the specimens. Besides, this method can significantly shorten the detect cycle comparing with Phenotypic DST. In this study, we established and evaluated the detection system of multi-drug resistance and extensively drug resistance in mycobacterium tuberculosis, which reflects mainly on: (1) The drug resistance of TB was detected by fluorescence PCR detection technology, which covered six anti-tuberculosis drugs with seven drug resistance genes. Additionally, a multidrugand extensively drug-resistant mutation detection system was established, and the results were statistically analyzed for 900 clinical sputum samples, and had high the specificity and sensitivity values; (2) The clinical diagnostic performance of PCR detection system was evaluated by testing 900 clinical specimens of mycobacterium tuberculosis, and the results were compared with the absolute concentration method of DST. In total coincidence rate, all of the six drugs were larger than $88 \%$, five of which drugs were larger than $90 \%$. 
Compared with phenotypic DST, the coincidence rates of rpoB(RFP), katG/inhA(INH), embB(EMB), gyrA(FQs), rpsL(SM) and rrs(AM) detected by fluorescent probe method were $95.89 \%, 91 \%, 92.11 \%, 90.89 \%, 88.11 \%$ and $93.22 \%$, respectively in this study. The coincidence rate of two methods of RIF, INH, EMB, FQs, AM resistance testing is higher than $90 \%$, only SM coincidence rate was $88.11 \%$, the mainly reason was that $\mathrm{rpoB}, \mathrm{katG} / \mathrm{inh} \mathrm{A}, \mathrm{embB}$, gyrA and $\mathrm{rrS}$ gene mutations of Mycobacterium tuberculosis were the main resistance mechanism of RFP, INH, EMB, FQs, AM. In addition to rpsL gene mutation (50-78\%), rrs gene mutation (20-30\%) is also the main molecular mechanism of drug resistant to SM [26, 27]. However, this study had not detect the rrs gene mutation locus of drug resistant to SM of Mycobacterium tuberculosis, which may be one of the reasons for the low consistency of SM drug resistance detected by PCR fluorescent probe method compared with phenotypic DST.

In This study, phenotypic DST was used as the standard, the detection rate of MDR-TB by phenotypic DST was 47.44\% (427/900), and the detection rate of rpoB and katG/inhA mutation was $42.22 \%$ (398/900) by PCR fluorescence probe method. The sensitivity, specificity, coincidence rate of PCR fluorescent probe method for detection of MDR-TB were $90.16 \%, 97.25 \%, 93.89 \%$, respectively. The detection rate of XDR -TB by phenotypic DST was $16.22 \%(146 / 900)$, and the detection rate of rpoB, katG/inhA, rpsL, rrS, embB, and gyrA by PCR fluorescence probe method was $15.22 \%$ (137/900), the sensitivity and specificity of PCR fluorescent probe method for detection of XDR-TB were $87.67 \%, 98.81 \%$, and the coincidence rate was $97.00 \%$.

The studies demonstrate that drug-resistant gene mutations are a major form of TB resistance. As for PCR fluorescence probe method, the positive detection rate was lower than DST, because drug-resistant gene mutation was just a form of drug resistance. Reducing cell's membrane vulnerability and efflux pump and inactivated enzymes changes, were also the causes of TB resistance. On the other hand, only a few loci of 7 common drug-resistant genes of 6 drugs were detected, while other drug-resistant genes or other drug-resistant loci were not developed in this study. For example, many genes reported in the literature such as ndh, efpA, kasA, iniABC operon (for INH resistance)[28], rpoC (for RFP resistance ) [29], embA, embC, ubiA (for EMB resistance) [30], and gyrB (for FQs resistance )[31]. These may be reasons for lower detection rate of PCR-fluorescent probe method than phenotypic DST.

\section{Conclusion}

With advantage of simple, accurate, specificity and high throughput, the PCR-fluorescent probe method will give impetus to the widely clinical application of molecular diagnostic technology $[27,28]$. We can reveal the association between mutation types, drug resistant type and dosage, clinical treatment and prognosis by distinguishing and investigating different mutation types of antituberculosis drugs and thereby offer a fresh perspective to anti-tuberculosis drugs' development so as to truly achieve prevention and control of tuberculosis. Hereby, we established a comprehensive detecting system of XDR-TB which including both first- and second-line anti-TB drugs. Additionally, developed genetic tests will inevitably produce more rapid results for drug-resistant isolates, which will lead to faster identification of MDR and XDR strains, more tailored treatment regimens, and a reduction in the transmission of TB.

\section{Declarations}

\section{Ethical Approval and Consent to participate}

All procedures were performed in compliance with the Ethic Committee of Chinese PLA General Hospital.

\section{Consent for publication}

All of the author's team members give permission to be acknowledged.

\section{Availability of supporting data}

The corresponding author of a manuscript, Dr. Liang and Dr. Xing, had full access to all the data in the study and takes responsibility for the integrity and availability of the data and the accuracy of the data analysis as well as the decision to submit for publication.

\section{Competing interests}


The authors declare no conflict of interest.

\section{Funding}

No funding.

\section{Authors' contributions}

All authors assisted in this study. LIANG Jianqin , ZHOU Jin , LIU Yuqin performed experiments, analyzed and interpreted data, prepared figures, and wrote the manuscript. XING Wanli designed experiments \analyzed and interpreted data囚and edited the manuscript. GAO Yuan囚XIANG Guangxin囚CHEN Zhi performed experiments囚evaluated data, and edited the manuscript.

\section{Acknowledgements}

No acknowledgements

\section{References}

1. World Health Orgnization. Global tuberculosis report 2019. Geneva: World Health Orgnization; 2019.

2. Ramaswamy SV, Amin AG, Göksel S, Stager CE, Dou SJ, El Sahly H, et al. Molecular genetic analysis of nucleotide polymorphisms associated with ethambutol resistance in human isolates of Mycobacterium tuberculosis. Antimicrob Agents Chemother. 2000;44(2):326-36.

3. Liu L, Jiang, Chen L, Zhao B, Dong J, Sun L, et al. The impact of combined gene mutations in inhA and ahpC genes on high levels of isoniazid resistance amongst katG non-315 in multidrug-resistant tuberculosis isolates from China. Emerg. Microbes Infect. 2018; 16;7(1):183.

4. Li Q, Dong HY, Pang Y, Xia H, Ou XC, Zhang ZY, et al. Multicenter evaluation of the molecular line probe assay for multidrug resistant Mycobacterium Tuberculosis detection in China. Biomed Environ Sci. 2015;28(6):464-7.

5. Zhang Y, Yew WW. Mechanisms of drug resistance in Mycobacterium tuberculosis. Int J Tuberc Lung Dis. 2009;13(11):1319.

6. Torres JN, Paul LV, Rodwell TC, Victor TC, Amallraja AM, Elghraoui A, et al. (2015). Novel katG mutations causing isoniazid resistance in clinical M. tuberculosis isolates. Emerg. Microbes Infect.2015;4(7): e42.

7. Campbell PJ, Morlock GP, Sikes RD, Dalton TL, Metchock B, Starks AM, et al. Molecular detection of mutations associated with first- and second-line drug resistance compared with conventional drug susceptibility testing of Mycobacterium tuberculosis. Antimicrob Agents Chemother. 2011;55(5):2032-41.

8. Maningi NE, Daum LT, Rodriguez JD, Said HM, Peters RPH, Sekyere JO, et al. Multi- and extensively drug resistant Mycobacterium tuberculosis in South Africa: a molecular analysis of historical isolates. J Clin Microbiol. 2018;56(5):e012141217.

9. Srivastava S, Ayyagari A, Dhole TN, Nyati KK, Dwivedi SK. embB nucleotide polymorphisms and the role of embB306 mutations in Mycobacterium tuberculosis resistance to ethambutol. Int J Med Microbiol. 2009;299(4):269-80.

10. Moure R, Espanol M, Tudo G, Vicente E, Coll P, Gonzalez-Martin J, et al. Characterization of the embB gene in Mycobacterium tuberculosis isolates from Barcelona and rapid detection of main mutations related to ethambutol resistance using a lowdensity DNA array. J Antimicrob Chemother. 2014;69(4):947-54.

11. He J, Zhu B, Yang Z, Hu B, Lin L, Zhang Q. Molecular analysis of the rpsL gene for rapid detection of streptomycin-resistant Mycobacterium tuberculosis: a meta-analysis. Scand J Infect Dis. 2014;46(8):585-92.

12. Maningi NE, Daum LT, Rodriguez JD, Said HM, Peters RPH, Sekyere JO, et al. Multi- and extensively drug resistant Mycobacterium tuberculosis in South Africa: a molecular analysis of historical isolates. J Clin Microbiol. 2018;56(5):e012141217.

13. Cheng AF, Yew WW, Chan EW, Chin ML, Hui MM, Chan RC. Multiplex PCR amplimer conformation analysis for rapid detection of gyrA mutations in fluoroquinnolone-resistant Mycobacterium tuberculosis clinical isolates. Antimicrob Agents Chemother. 2004;48(2):596-601. 
14. Evans J, Segal H. Evans J, et al. Novel multiplex allele-specific PCR assays for the detection of resistance to second-line drugs in Mycobacterium tuberculosis. J Antimicrob Chemother. 2010;65(5):897-900.

15. Almeida Da Silva PE, Palomino JC. Molecular basis and mechanisms of drug resistance in Mycobacterium tuberculosis: classical and new drugs. J Antimicrob Chemother. 2011 Jul;66(7):1417-30.

16. Morlock GP, Crawford JT, Butler WR, Brim SE, Sikes D, Mazurek GH, et al. Phenotypic characterization of pncA mutants of Mycobacterium tuberculosis. Antimicrob Agents Chemother. 2000;44(9):2291-5.

17. Denkinger CM, Kik SV, Cirillo DM, Casenghi M, Shinnick T, Weyer K, et al. Defining the needs for next generation assays for tuberculosis. J Infect Dis. 2015;211(Suppl 2(Suppl 2):29-38.

18. Mertaniasih NM, Soedarsono, Kusmiati T, Koendhori EB, Kusumaningrum D, Koesprijani, et al. Difficulties with the implemented xpert MTB/RIF for determining diagnosis of pulmonary and extrapulmonary tuberculosis in adults and children. J Clin Tuberc Other Mycobact Dis. 2020;19:100159. doi:10.1016/j.jctube.2020.100159.

19. WHO. Automated real-time nucleic acid amplification technology for rapid and simultaneous detection of tuberculosis and rifampicin resistance: Xpert MTB/RIF assay for the diagnosis of pulmonary and extrapulmonary TB in adults and children. In: Policy update. Geneva: World Health Organization; 2013.

20. Kaur R, Kachroo K, Sharma JK, Vatturi SM, Dang A. Diagnostic Accuracy of Xpert Test in Tuberculosis Detection: A Systematic Review and Meta-analysis. J Glob Infect Dis. 2016;8(1):32-40.

21. Meyer AJ, Atuheire C, Worodria W, Kizito S, Katamba A, Sanyu I, et al. Sputum quality and diagnostic performance of GeneXpert MTB/RIF among smear-negative adults with presumed tuberculosis in Uganda. PLoS One. 2017;12(7):e0180572.

22. Zhao YL, Liu ZMTB Laboratory Standardization Operation and Network Establishment.Beijing, People's Medical Publishing House,2013.

23. Liang JQ, Gao HF, Li HM, Zhao ZX, Zhang GY, Wang JH, et al. Study on the reliability of detecting Mycobacteria in sputum specimens by PCR-fluorescent probe. Chin J Antituberc. 2012;34(5):271-4.

24. An P, Nelson GW, Wang L, Donfield S, Goedert JJ, Phair J, et al. Modulating influence on HIV/AIDS by interacting RANTES gene variants. Proc Natl Acad Sci U S A. 2002 Jul 23;99(15):10002-10007.

25. WHO. Rapid implementation of the Xpert MTB/RIF diagnostic test. Geneva: World Health Organization; 2011.

26. Tudo G, Rey E, Borrell S, Alcaide F, Codina G, Coll P, et al. Characterization of mutations in streptomycin-resistant Mycobacterium tuberculosis clinical isolates in the area of Barcelona. J Antimicrob Chemother. 2010;65(11):2341-6.

27. Sun YJ, Luo JT, Wong SY, Lee AS. Analysis of rpsL and rrs mutations in Beijing and non-Beijing streptomycin-resistant Mycobacterium tuberculosis isolates from Singapore. Clin Microbiol Infect. 2010;16(3):287-9.

28. Nguyen L. Antibiotic resistance mechanisms in M. tuberculosis: an update. Arch Toxicol. 2016;90(7):1585-604.

29. Perdigao J, Gomes P, Miranda A, Maltez F, Machado D, Silva, et al. Using genomics to understand the origin and dispersion of multidrug and extensively drug resistant tuberculosis in Portugal. Sci Rep. 2020;10(1):2600.

30. Farhat MR, Sultana R, lartchouk O, Bozeman S, Galagan J, Sisk P, et al. (2016). Genetic determinants of drug resistance in Mycobacterium tuberculosis and their diagnostic value. Am J Respir Crit Care Med. 2016;194(5):621-630.

31. Farhat MR, Jacobson KR, Franke MF, Kaur D, Sloutsky A, Mitnick CD, et al. Gyrase mutations are associated with variable levels of fluoroquinolone resistance in Mycobacterium tuberculosis. J Clin Microbiol. 2016;54(3):727-33.

\section{Tables}


Table 1

Drug resistance detection of 900 clinical sputum specimens

\begin{tabular}{|c|c|c|c|c|c|c|}
\hline \multirow{2}{*}{$\begin{array}{l}\text { Phenotypic drug susceptibility testing } \\
\text { (DST) }\end{array}$} & \multirow[t]{2}{*}{ Cases } & \multirow[t]{2}{*}{ Locus } & \multicolumn{2}{|c|}{ PCR-fluorescent probe } & \multicolumn{2}{|c|}{ Sequencing } \\
\hline & & & Types & Cases & Mutation & Cases \\
\hline \multirow[t]{8}{*}{ RIF-resisant } & \multirow[t]{8}{*}{501} & \multirow[t]{8}{*}{ rpoB } & \multirow{8}{*}{$\begin{array}{l}\text { Mutant } \\
\text { type }\end{array}$} & \multirow[t]{8}{*}{480} & T511C & 40 \\
\hline & & & & & A526G & 35 \\
\hline & & & & & C526G & 39 \\
\hline & & & & & C526T & 95 \\
\hline & & & & & A526T & 35 \\
\hline & & & & & A516T & 29 \\
\hline & & & & & C531T & 182 \\
\hline & & & & & T533C & 25 \\
\hline RIF-susceptible & 399 & rpoB & Wild type & 420 & $\begin{array}{l}\text { Without } \\
\text { mutation }\end{array}$ & 420 \\
\hline \multirow[t]{3}{*}{ INH-resisant } & \multirow[t]{3}{*}{451} & \multirow[t]{2}{*}{ katG } & \multirow{3}{*}{$\begin{array}{l}\text { Mutant } \\
\text { type }\end{array}$} & 241 & G315C & 199 \\
\hline & & & & 145 & G315A & 42 \\
\hline & & $\operatorname{inh} A$ & & & $\mathrm{C}-15 \mathrm{~T}$ & 145 \\
\hline INH-susceptible & 449 & $\begin{array}{l}\text { katG / } \\
\text { inhA }\end{array}$ & Wild type & 514 & $\begin{array}{l}\text { Without } \\
\text { mutation }\end{array}$ & 514 \\
\hline \multirow[t]{2}{*}{ EMB-resistant } & \multirow[t]{2}{*}{235} & \multirow[t]{2}{*}{$e m b B$} & \multirow{2}{*}{$\begin{array}{l}\text { Mutant } \\
\text { type }\end{array}$} & \multirow[t]{2}{*}{190} & A306G & 101 \\
\hline & & & & & G306A & 89 \\
\hline EMB-susceptible & 665 & $e m b B$ & Wild type & 710 & $\begin{array}{l}\text { Without } \\
\text { mutation }\end{array}$ & 710 \\
\hline \multirow[t]{2}{*}{ FQs-resistant } & \multirow[t]{2}{*}{293} & \multirow[t]{2}{*}{ gyrA } & \multirow{2}{*}{$\begin{array}{l}\text { Mutant } \\
\text { type }\end{array}$} & \multirow[t]{2}{*}{239} & С90T & 75 \\
\hline & & & & & A94G & 164 \\
\hline FQs- susceptible & 607 & gyrA & Wild type & 661 & $\begin{array}{l}\text { Without } \\
\text { mutation }\end{array}$ & 661 \\
\hline \multirow[t]{2}{*}{ SM-resistant } & \multirow[t]{2}{*}{425} & \multirow[t]{2}{*}{$r p s L$} & \multirow{2}{*}{$\begin{array}{l}\text { Mutant } \\
\text { type }\end{array}$} & \multirow[t]{2}{*}{342} & A43G & 268 \\
\hline & & & & & A88G & 74 \\
\hline SM-susceptible & 475 & rpsL & Wild type & 558 & $\begin{array}{l}\text { Without } \\
\text { mutation }\end{array}$ & 558 \\
\hline \multirow[t]{3}{*}{ AM-resistant } & \multirow[t]{3}{*}{204} & \multirow[t]{3}{*}{ rrs } & Mutant & 163 & A1401G & 103 \\
\hline & & & & & $\mathrm{C} 1402 \mathrm{~T}$ & 32 \\
\hline & & & & & G1484T & 28 \\
\hline AM-susceptible & 696 & rrs & Wild type & 737 & $\begin{array}{l}\text { Without } \\
\text { mutation }\end{array}$ & 737 \\
\hline
\end{tabular}


Table 2

Statistical analysis of detecting clinical sputum specimens by PCR-fluorescent probe method and phenotypic DST

\begin{tabular}{|c|c|c|c|c|c|c|}
\hline \multirow[t]{2}{*}{ PCR-fluorescent probe } & & \multicolumn{2}{|l|}{ DST } & \multicolumn{3}{|c|}{ Accuracy values } \\
\hline & & Resistant & Susceptible & Sensitivity(\%) & Specificity(\%) & $\begin{array}{l}\text { Total } \\
\text { coincidence(\%) }\end{array}$ \\
\hline \multirow[t]{2}{*}{ RFP (rpoB) } & $\begin{array}{l}\text { Mutant } \\
\text { type }\end{array}$ & 472 & 8 & \multirow[t]{2}{*}{$94.21 \%$} & \multirow[t]{2}{*}{$97.99 \%$} & \multirow[t]{2}{*}{$95.89 \%$} \\
\hline & $\begin{array}{l}\text { Wild } \\
\text { type }\end{array}$ & 29 & 391 & & & \\
\hline \multirow[t]{2}{*}{ INH (katG/inhA) } & $\begin{array}{l}\text { Mutant } \\
\text { type }\end{array}$ & 378 & 8 & \multirow[t]{2}{*}{$83.81 \%$} & \multirow[t]{2}{*}{$98.22 \%$} & \multirow[t]{2}{*}{$91.00 \%$} \\
\hline & $\begin{array}{l}\text { Wild } \\
\text { type }\end{array}$ & 73 & 441 & & & \\
\hline \multirow[t]{2}{*}{ EMB (embB) } & $\begin{array}{l}\text { Mutant } \\
\text { type }\end{array}$ & 177 & 13 & \multirow[t]{2}{*}{$75.32 \%$} & \multirow[t]{2}{*}{$98.05 \%$} & \multirow[t]{2}{*}{$92.11 \%$} \\
\hline & $\begin{array}{l}\text { Wild } \\
\text { type }\end{array}$ & 58 & 652 & & & \\
\hline \multirow[t]{2}{*}{ FQs (gyrA) } & $\begin{array}{l}\text { Mutant } \\
\text { type }\end{array}$ & 225 & 14 & \multirow[t]{2}{*}{$76.79 \%$} & \multirow[t]{2}{*}{$97.69 \%$} & \multirow[t]{2}{*}{$90.89 \%$} \\
\hline & $\begin{array}{l}\text { Wild } \\
\text { type }\end{array}$ & 68 & 593 & & & \\
\hline \multirow[t]{2}{*}{$\mathrm{SM}(\mathrm{rpsL})$} & $\begin{array}{l}\text { Mutant } \\
\text { type }\end{array}$ & 330 & 12 & \multirow[t]{2}{*}{$77.65 \%$} & \multirow[t]{2}{*}{$97.47 \%$} & \multirow[t]{2}{*}{$88.11 \%$} \\
\hline & $\begin{array}{l}\text { Wild } \\
\text { type }\end{array}$ & 95 & 463 & & & \\
\hline \multirow[t]{2}{*}{ AM (rrs) } & $\begin{array}{l}\text { Mutant } \\
\text { type }\end{array}$ & 153 & 10 & \multirow[t]{2}{*}{$75.00 \%$} & \multirow[t]{2}{*}{$98.56 \%$} & \multirow[t]{2}{*}{$93.22 \%$} \\
\hline & $\begin{array}{l}\text { Wild } \\
\text { type }\end{array}$ & 51 & 686 & & & \\
\hline \multirow{2}{*}{$\begin{array}{l}\text { MDR } \\
\text { (rpoB, katG/inhA) }\end{array}$} & $\begin{array}{l}\text { Mutant } \\
\text { type }\end{array}$ & 385 & 13 & \multirow[t]{2}{*}{$90.16 \%$} & \multirow[t]{2}{*}{$97.25 \%$} & \multirow[t]{2}{*}{$93.89 \%$} \\
\hline & $\begin{array}{l}\text { Wild } \\
\text { type }\end{array}$ & 42 & 460 & & & \\
\hline \multirow[t]{2}{*}{$\begin{array}{l}\text { XDR } \\
\text { (rpoB,katG/inhA,gyrA,embB,rpsL/rrs) }\end{array}$} & $\begin{array}{l}\text { Mutant } \\
\text { type }\end{array}$ & 128 & 9 & \multirow[t]{2}{*}{$87.67 \%$} & \multirow[t]{2}{*}{$98.81 \%$} & \multirow[t]{2}{*}{$97.00 \%$} \\
\hline & $\begin{array}{l}\text { Wild } \\
\text { type }\end{array}$ & 18 & 745 & & & \\
\hline
\end{tabular}


Table 3

Statistical analysis of detecting clinical sputum specimens by PCR-fluorescent probe method and PCR-DS

\begin{tabular}{|c|c|c|c|c|c|c|}
\hline \multicolumn{2}{|c|}{ PCR-fluorescent probe } & \multicolumn{2}{|l|}{ PCR-DS } & \multicolumn{3}{|c|}{ Accuracy values } \\
\hline & & Mutant type & Wild type & Sensitivity(\%) & Specificity(\%) & Total coincidence(\%) \\
\hline \multirow[t]{2}{*}{ rpoB } & mutant type & 480 & 0 & $100 \%$ & $100 \%$ & $100 \%$ \\
\hline & wild type & 0 & 420 & & & \\
\hline \multirow[t]{2}{*}{ katG } & mutant type & 241 & 0 & $100 \%$ & $100 \%$ & $100 \%$ \\
\hline & wild type & 0 & 659 & & & \\
\hline \multirow[t]{2}{*}{$\operatorname{inh} A$} & mutant type & 145 & 0 & $100 \%$ & $100 \%$ & $100 \%$ \\
\hline & wild type & 0 & 755 & & & \\
\hline \multirow[t]{2}{*}{$e m b B$} & mutant type & 190 & 0 & $100 \%$ & $100 \%$ & $100 \%$ \\
\hline & wild type & 0 & 710 & & & \\
\hline \multirow[t]{2}{*}{ gyrA } & mutant type & 239 & 0 & $100 \%$ & $100 \%$ & $100 \%$ \\
\hline & wild type & 0 & 661 & & & \\
\hline \multirow[t]{2}{*}{$r p s L$} & mutant type & 342 & 0 & $100 \%$ & $100 \%$ & $100 \%$ \\
\hline & wild type & 0 & 558 & & & \\
\hline \multirow[t]{2}{*}{ rrs } & mutant type & 163 & 0 & $100 \%$ & $100 \%$ & $100 \%$ \\
\hline & wild type & 0 & 737 & & & \\
\hline
\end{tabular}

